\title{
Treatment of Wastewater from Bean Sprout Production for Reuse
}

\author{
Inés Burgos-Luján ${ }^{1} \&$ Anthony Z. Tong ${ }^{1}$ \\ ${ }^{1}$ Department of Chemistry, Acadia University, Wolfville, NS, Canada \\ Correspondence: Anthony Z. Tong, Department of Chemistry, Acadia University, 6 University Avenue, Wolfville \\ B4P 2R6, NS, Canada. Tel: 1-902-585-1355. E-mail: anthony.tong@acadiau.ca
}

Received: December 24, 2016

doi:10.5539/ep.v7n1p1

\author{
Accepted: January 3, $2017 \quad$ Online Published: November 3, 2017 \\ URL: https://doi.org/10.5539/ep.v7n1p1
}

\begin{abstract}
Bean sprout production consumes a significant volume of municipal water and generates a similar amount of wastewater. Water costs become a serious concern for this food industry, therefore wastewater reuse is highly desired by many sprout producers. Bean sprout wastewater has a relatively low level of contamination, which gives a great potential for reuse. The objective of this study was to exam the treatment feasibility of sprout production wastewater using a membrane bioreactor. Real-world wastewater from a sprout producer was treated continuously for 35 days. Important water quality parameters were monitored closely including chemical oxygen demand (COD), ammonia, tannins, $\mathrm{pH}$, total suspended solids (TSS), etc. Once the biological system was stabilized, the MBR's effluent showed very low level of COD, ammonia, TSS and bacteria, which demonstrated that the reuse of sprout wastewater is achievable.
\end{abstract}

Keywords: bean sprout, effluent, treatment, membrane bioreactor, reuse

\section{Introduction}

Manufacturers in food processing industry use a significant amount of water for growing, washing and cleaning. Due to low water absorption, food processers usually produce a similar quantity of effluent wastewater that is normally dumped into municipal sewer systems or surface waters (Mavrov and Bélières, 2000). In many cases, the effluent is often relatively clean with low chemical oxygen demand (COD $<100 \mathrm{mg} / \mathrm{L})$, which gives a great potential to recycle the wastewater for both economic and environmental benefits. Therefore, demand for water treatment and reuse technologies in the food processing industry is increasing (Casani et al., 2005). On the other hand, environmental legislation on freshwater conservation and pollution abatement becomes more stringent, making manufacturers to find sustainable ways in their production including wastewater treatment and reuse (Cisneros et al., 2008). Although the most significant barrier to install a water treatment facility remains in its cost, the benefits of water reuse and improved water quality can overtake, which becomes more and more important in decision making (Judd, 2011).

This study focused on effluent wastewater from bean sprout production. Effluent samples were obtained from a bean sprout producer in Toronto, Canada that consumes about $200 \mathrm{~m}^{3} /$ day of municipal drinking water and a comparable amount of wastewater discharged down to the municipal sewage. Costs of drinking water consumption and wastewater discharging became a considerable financial burden to the firm. The objective of the study was to investigate water quality of the bean sprout effluent and the feasibility of its treatment using a laboratory-scale membrane bioreactor (MBR). To the authors' knowledge, treatment of bean sprout wastewater has not been reported in the literature.

MBR is a biological treatment technology where organic wastes are decomposed by microorganisms, while microorganisms are retained by ultra-filtration membrane (Stephenson et al., 2000). The polymeric membrane usually has a tubular structure with micro-pores $(20-100 \mathrm{~nm})$ that can effectively block microorganisms, suspended debris and proteins from passing through. Due to its enrichment of microorganisms by membrane filtration, MBR usually shows much better treatment efficiency than the conventional activated sludge method. The MBR technology has been applied in treating municipal wastewater (Judd, 2011), pesticide-contaminated wastewater (Ghoshdastidar et al., 2012; Ghoshdastidar and Tong, 2013), compost leachate (Brown et al., 2013), and oily wastewater (Sichinga et al., 2015).

The study focused on several critical water quality parameters in water reuse for food production purpose, including COD, ammonia, total suspended solids (TSS), bacteria, $\mathrm{pH}$, etc. COD estimates the total amount of 
organic materials in wastewater. It is determined by measuring the amount of oxygen needed to oxidize organic matters present in the wastewater sample using chemical oxidation (Nollet and De Gelder, 2007). During aerobic treatment, organic matters are transformed to smaller and less toxic organic molecules including carbon dioxide (Najafi and Ma, 2009). Ammonia is also generated in biodegrdation of nitrogen-containing substrances that are usually plenty in food wastewater. Ammonia nitrogen may take up to $60 \%$ of the total nitrogen amount in untreated wastewaters (Cheremisinoff, 1994). Ammonia is a toxic substance and should be treated before reuse. In the bacterial nitrification and nitration processes, ammonia is converted less toxic nitrite and then nitrate. The heterotrophic plate counts (HPC) are used to express the total amount of bacteria in wastewater. HPC can be correlated to TSS, because bacteria are normally attached to the suspended solids in wastewater (Goulder, 1977). In a MBR treatment system, both HPC and TSS can be easily managed due to the micro-pore filtration membrane (Judd, 2011).

\section{Methods}

\subsection{Sample Collection}

Sprout production wastewater was collected in two 200-L barrels: one was taken from a product line of green bean sprouts only, while the other was a mixture of effluents of producing green bean sprouts and barley sprouts. The barrels were transported and stored in a concrete bunker that had a temperature about $8{ }^{\circ} \mathrm{C}$ during the experimental period. No preservatives or other additives were added. During the first 18 days the green bean sprout barrel was used. The second barrel sample was processed after Day 18.

\subsection{Membrane Bioreactor}

The laboratory MBR contained a SuperUF membrane module (Super-string MBR Technology Corp, China) that was submerged in a $20 \mathrm{~L}$ cylindrical tank. The temperature of the MBR system was maintained at $25 \pm 1{ }^{\circ} \mathrm{C}$, which simulated a typical indoor ambient temperature and was a necessary condition for optimal bacterial degradation (Ghoshdastidar et al., 2012). The bioreactor was aerated at $300 \mathrm{~L} /$ hour through a sparger at the bottom of the bioreactor to ensure adequate aerobic condition (Ghoshdastidar et al., 2012). The MBR system was initiated with $2 \mathrm{~L}$ of activated sludge obtained from the municipal sewage treatment plant in Wolfville, Nova Scotia, and then left to stabilize for two days before treatment experiment. The bean sprout wastewater was pumped into the bioreactor at a rate of $7.6 \mathrm{~L} /$ day using a peristaltic pump, which gave a hydraulic retention time of 63 hours.

\subsection{Analysis of Water Quality Parameters}

Important water quality parameters were monitored daily during the experimental period. Most parameters were analyzed using a HACH DR2800 spectrophotometer. The COD measurement was determined by the reactor digestion method, approved by USEPA (Hach Company, 2005). Ammonia TNT 830 Kit from HACH Canada (Ontario, Canada) was chosen for measuring ammonia in the ultra-low range. The USEPA PhosVer3 method was used to monitor phosphorus reactive. Monochloramine was measured in the low range using the indophenol method. Tannins and lignins were tested using the tyrosine method. An older HACH DR2000 spectrophotometer was used to measure total suspended solids (TSS). The $\mathrm{pH}$, total dissolved solids (TDS), and dissolved oxygen (DO) were measured using a HACH HQ 40d multimeter.

Microbiological analysis was conducted daily to monitor the population of heterotrophic bacteria in the MBR effluent. Agar plates were prepared according to the Standard Methods for the Examination of Water and Wastewater (Clesceri, 1989). A small amount of the MBR effluent sample was placed in a test tube containing saline solution and subsequent dilutions were made if necessary. A $100 \mu \mathrm{L}$ of the final dilution mixture was inoculated on the agar plate and spread evenly on the plate. The agar plate was placed in an incubator at $36{ }^{\circ} \mathrm{C}$ for 48 hours. The total number of colonies on the plate was counted in colony forming units $(\mathrm{CFU} / \mathrm{mL})$. The measurements were completed in triplicate.

In measuring mixed liquor suspended solids (MLSS) and mixed liquor volatile suspended solids (MLVSS), 100 $\mathrm{mL}$ of sludge samples were taken from the bioreactor, and filtered using glass fiber filters. These filters were then baked at $105^{\circ} \mathrm{C}$ for MLSS and $500{ }^{\circ} \mathrm{C}$ for MLVSS, respectively. Weights of filters were measured using an analytical balance.

\section{Results and Discussion}

\subsection{Wastewater Quality}

Two barrels of wastewater samples were included in this study. One came from pure green bean sprout production, while the other contained effluents from both green bean sprout and barley sprout lines. Important 
wastewater quality parameters were determined for both types of wastewater and their results are tabulated in Table 1. Both types of wastewater had relatively low contamination level with CODs less than $60 \mathrm{mg} / \mathrm{L}$ and ammonia nitrogen less than $1 \mathrm{mg} / \mathrm{L}$. This provided good potential for reuse after treatment. Nevertheless, the mix wastewater of green bean and barley sprouts showed higher levels of contamination than the wastewater from green bean alone. COD and ammonia of the mix were 2.4 and 9.6 times higher than that of the green bean sprout wastewater, respectively. The switch of wastewater on Day 19 affected the ammonia in the MBR effluent as discussed in the following.

Table 1. Water quality parameters of the wastewater and MBR effluent after treatment

\begin{tabular}{cccccc}
\hline & Units & GBSW & GBBSW & Eff35 & \% Removal \\
\hline COD & $\mathrm{mg} / \mathrm{L}$ & 22.3 & 52.8 & 10.7 & 79 \\
Ammonia & $\mathrm{mg} / \mathrm{L}$ & 0.071 & 0.680 & 0.038 & 94 \\
Monochloramine & $\mathrm{mg} / \mathrm{L}$ & 3.75 & 4.18 & 1.79 & 57 \\
Tannins & $\mathrm{mg} / \mathrm{L}$ & 3.0 & 4.3 & 0.5 & 88 \\
pH & & 6.7 & 6.6 & 7.3 & \\
TSS & $\mathrm{mg} / \mathrm{L}$ & 5 & 6 & 1 & 83 \\
HPC & CFU/L & $1.60 \times 10^{4}$ & $6.13 \times 10^{4}$ & $1.18 \times 10^{3}$ & 98 \\
\hline
\end{tabular}

GBSW: Green bean sprout wastewater used from Day 1 to 18

GBBSW: Green bean and barley sprout wastewater used from Day 19 to 35

Eff35: MBR effluent on Day 35

Table 1 also shows the MBR effluent quality after 35 days of treatment using a laboratory scale MBR. Results demonstrated that the treatment was a success. COD, ammomium nitrogen and total suspended solids were reduced to $10.7,0.038$ and $1 \mathrm{mg} / \mathrm{L}$, respectively, which corresonded to removal rates of $79 \%, 94 \%$ and $83 \%$. Further, the MBR effluent was almost free of microorganism by reduction of $98 \%$ of HTPC. Details of treatment results are discussed in the following.

\section{$3.2 \mathrm{pH}$ and $\mathrm{DO}$}

The $\mathrm{pH}$ and dissolved oxygen (DO) are critical parameters of a MBR and they were monitored closely to ensure optimal operational conditions of the MBR. The $\mathrm{pH}$ was fairly stable during the experimental period (Figure 1a). The average $\mathrm{pH}$ was $7.38 \pm 0.16$. Some fluctuations of $\mathrm{pH}$ were shown at the beginning of experiment, but it stablized after Day 10. A neatrual $\mathrm{pH}$ condition is the ideal for treating wastewater using a MBR method (Judd, 2011).

The DO during the entire experiment varied in a range from 5.0 to $9.5 \mathrm{mg} / \mathrm{L}$ (Figure $1 \mathrm{~b}$ ). The average DO was $8.32 \pm 0.97 \mathrm{mg} / \mathrm{L}$. There were some minor drops of DO on Days 9, 11 and 19, but the MBR system recovered quickly in the next day. This range of DO provided an ideal level of oxygen for an aerobic bioreactor and promoted the bacterial population growth (Knobelsdorf Miranda, 2005). 


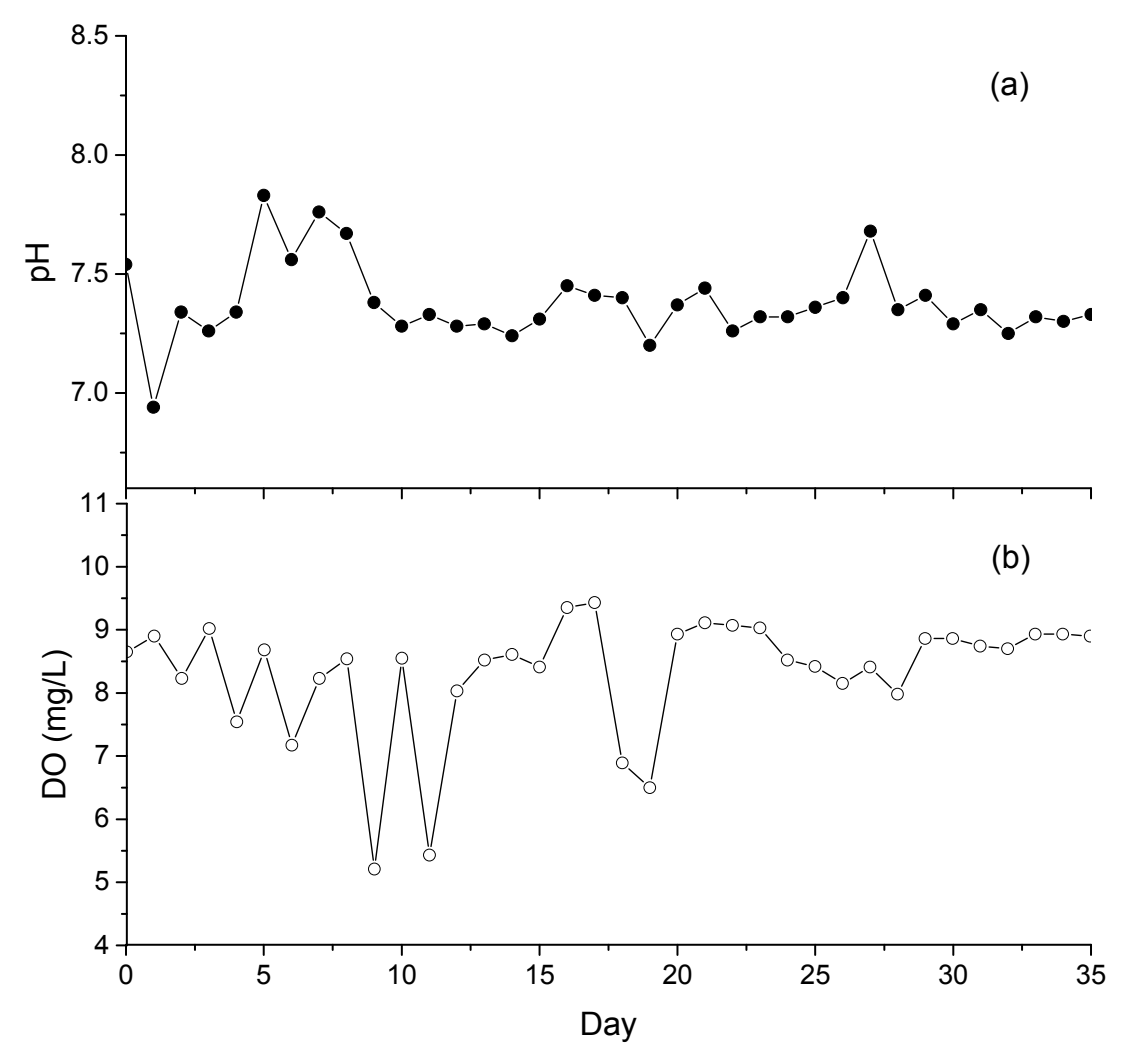

Figure 1. $\mathrm{pH}$ and dissolved oxygen in the MBR effluent

\subsection{COD, Tannins and Ammonia}

The COD was relatively stable and varied insignificantly between 10 and $20 \mathrm{mg} / \mathrm{L}$ in almost the entire experimental period, except from Day 6 to 8 (Figure 2a). This COD peak was caused by a fissure on the MBR membrane which resulted in leaking actived sludge into the effluent. The membrane module was replaced with a new one once the problem was detected. Because of the low COD in the grean-bean sprout wastewater (22.0 $\mathrm{mg} / \mathrm{L}$ ), introduction of this wastewater did not increase the effluent COD. It was also interesting to notice that the effluent COD remained constant even after the mixed wastewater $(\mathrm{COD}=52.8 \mathrm{mg} / \mathrm{L})$ was introduced after Day 18. This demonstrated that the MBR system reached a steady state for decomposing organic material; and small change in organic loading had minimal impact to the system.

Tannins are a class of polyphenols in plant matters with molecular weights from 500 to 3,000. They are commonly founded in wastewater from forestry, plant medicine, paper industries and food production. High concentration of tannins may inhibit the rate of biodegrdation using microorganisms (He et al., 2007). Tannins were $13.5 \%$ and $8.1 \%$ of COD in the green bean sprout wastewater and the mix wastewater. During the 35 days of treatment, concentration variations of COD and tannins were similar (Figure 2b). Tannins also showed a peak concentration due to the leaking problem of the membrane. When the mix wastewater was introduced on Day 19, the concentration of tannins remained stable. It was interesting to notice that the ratio of tannin/COD in the MBR effluent on Day 35 was reduced to $1.4 \%$, which was significantly less than that in the two types of wastewater. This indicated that the MBR method was more efficient in removing tannins than other organic matters, while the inibition effect of biodegrdation was not observed.

The ammonia level in the effluent was farily low and stable at an avearge of $0.035 \mathrm{mg} / \mathrm{L}$ in treating the first barrel of the green bean sprout sample (Figure 2c). Once the second barrel was introduced on Day 19, the ammonium concentration increased considerably for several days until the stabilization appeared again on Day 31. Such a change of ammonium concentration was not observed in the COD profile, which indicated that nitrifying bacterial population was low or they took more time to adapt to the change of environment. 


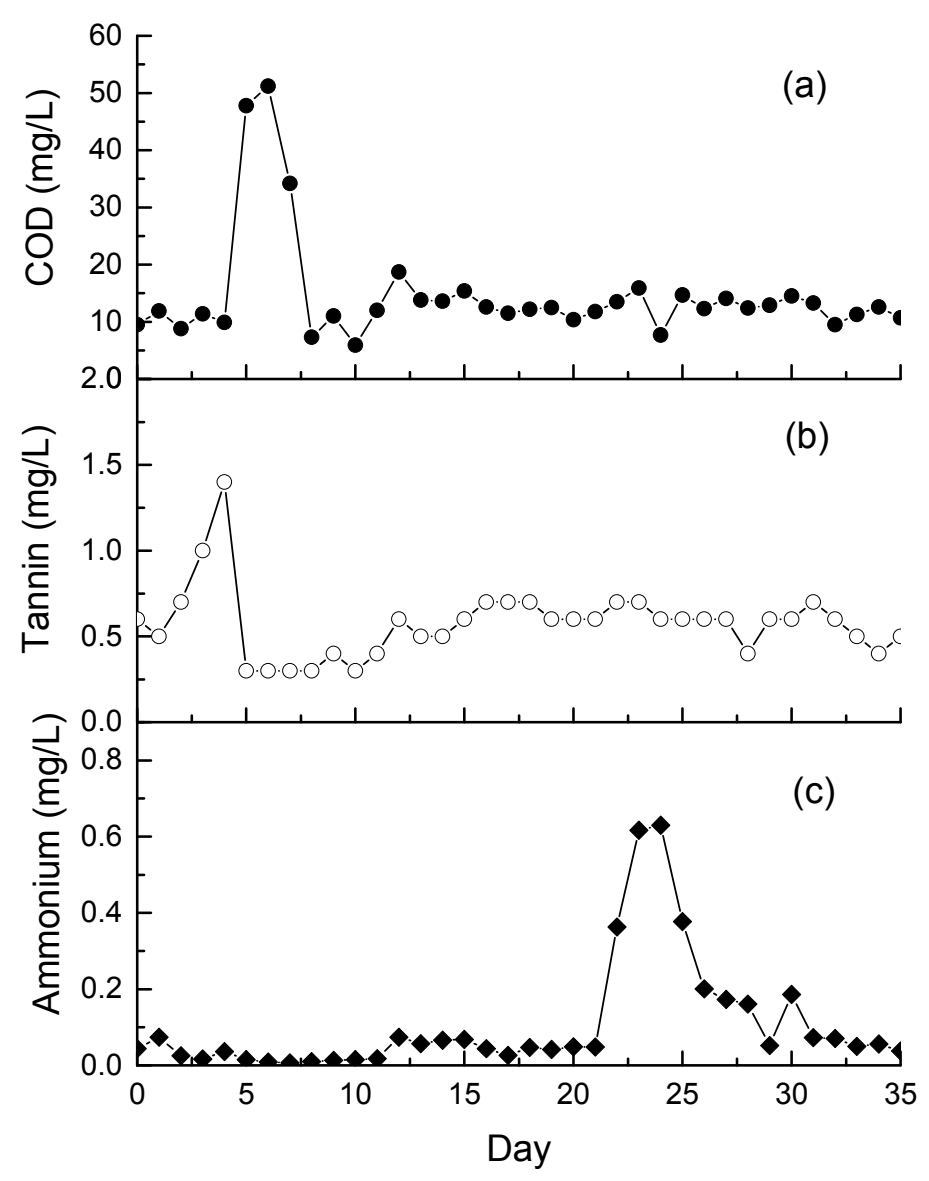

Figure 2. COD, tannins and ammonium in the MBR effluent

\subsection{TSS and HTPC}

TSS in the MBR effluent decrased gradually from $25 \mathrm{mg} / \mathrm{L}$ on Day 1 to $1 \mathrm{mg} / \mathrm{L}$ on Day 6 and then remained very low in rest days of the experiment (Figure 3a). The initial higher value of TSS was likely caused by the fissure on the membrane at the beginning of experiment. Due to filtration of the membrane, the final MBR effluent was free of TSS. That being said, the two sprout production wastewater had low TSS levels ( 5 and $6 \mathrm{mg} / \mathrm{L}$ ). Hence, removal of TSS was easy to achieve.

In order to reuse bean sprount wastewater, the MBR effuent should have a low level of microorganisms. The ultrafiltration membrane used in a MBR system provides an advantage of removing a great deal of bacterial population. On the other side, bacterial population needs to be high in the bioreactor to achieve optimal treatment efficiency. The heterotrophic plate counts (HPC) in the MBR effluent were monitored daily during the experimental period (Figure 3b). Due to the fissure on the MBR membrane, the MBR effluent had high initial bacterial counts. However, after replacing the broken membrane on Day 5, the bacterial population kept increasing to $3.3 \times 10^{5} \mathrm{CFU} / \mathrm{mL}$ on Day 11. A 18-watt UV lamp was added on Day 11 to solve the microorganism problem in the effluent. The UV method effectively reduced the HPC to $166 \mathrm{CFU} / \mathrm{mL}$ on Day 12 and the result was stable until the end of experiment. In comparision to a HPC of $1.6 \times 10^{4} \mathrm{CFU} / \mathrm{mL}$ in the bean sprout wastewater, $99 \%$ of bacteria was removed from the wastewater. 


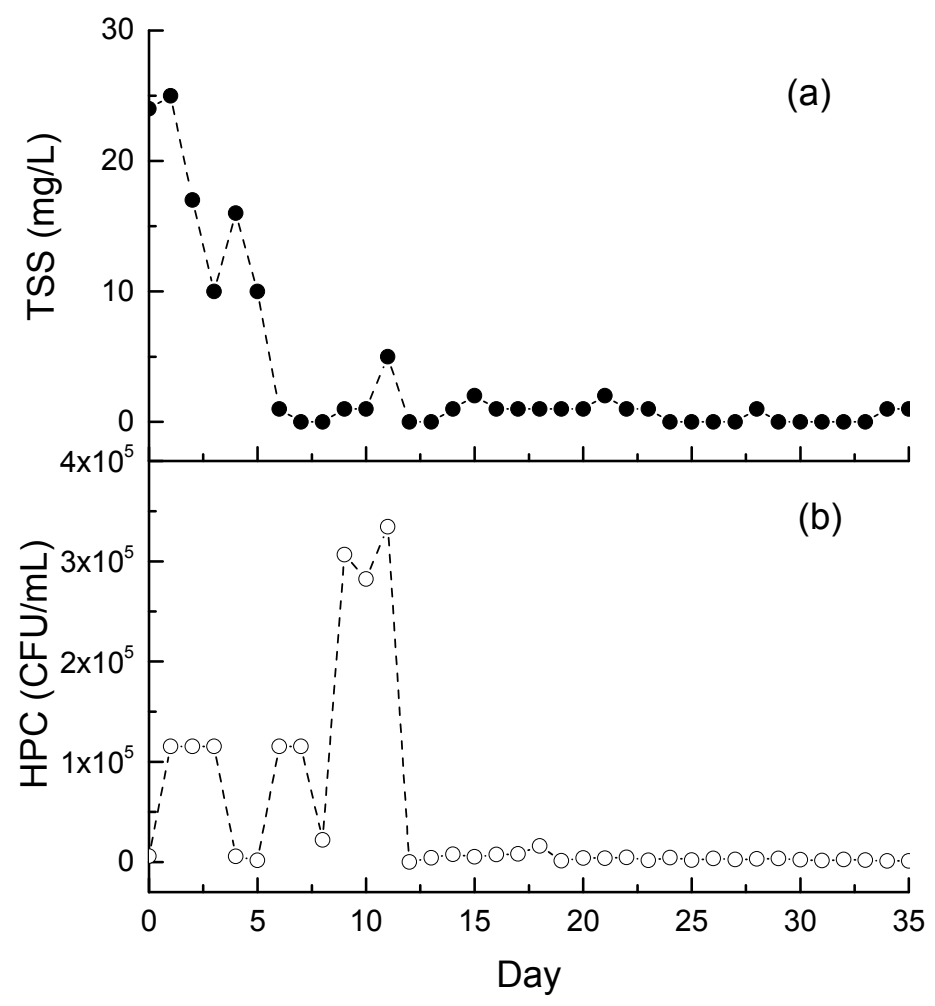

Figure 3. TSS and HPC in the MBR effluent

Ultrafiltration alone was not enough to completely eliminate microorganisms. Microorganisms have various shape and size. Some sub-micron virus and bacteria might leak out from membrane or fittings and present in the MBR effluent. US EPA suggests that the maximum colonies allowed are $500 \mathrm{CFU} / \mathrm{mL}$ for drinking water (U.S. Environmental Protection Agency, 2011), nevertheless, this MBR effluent had 1,183 CFU/mL on Day 35. The HPC result could be further improved using nanometer size filtration such as reverse osmosis. However, this HPC level would not be considered as a problem, because the water reuse was desired for sprout production rather than drinking.

\subsection{MLSS and MLVSS}

The mixed liquor suspended solids (MLSS) and the mixed liquor volatile suspended solids (MLVSS) were measured to understand the activated sludge in the bioreactor. Those 2 parameters are closely related and the MLVSS indicates the bacterial population in the sludge (Woodside and Kocurek, 1997). Both MLSS and MLVSS dropped during the first 6 days due to the fissure on the membrane surface (Figure 4a). Considering the TSS of the bean sprout was only $5 \mathrm{mg} / \mathrm{L}$, introdiction of wastewater actually reduced suspected solids in the bioreactor. Once the fissure was fixed, both MLSS and MLVSS increased steadily. Introduction of the second barrel of wastewater did not affect much these measurements, because the suspended solids and dissolved solids of both samples were close. The ratio of MLVSS/MLSS had of peak of 2.4 on Day 6 (Figure 4b) with MLSS and MLVSS values of 5 and $12 \mathrm{mg} / \mathrm{L}$, respectively. These small values were close to the uncertainty of the analytical balance used in the experiment, therefore the high ratio on Day 6 was not accurate. Except Days 5 and 6, the ratio of MLSS/MLSS had an overall trend of increase from 0.343 on Day 1 to 0.789 on Day 35, which indicated that the bacterial population in the activated sludge grew steadily during the experimental period. 


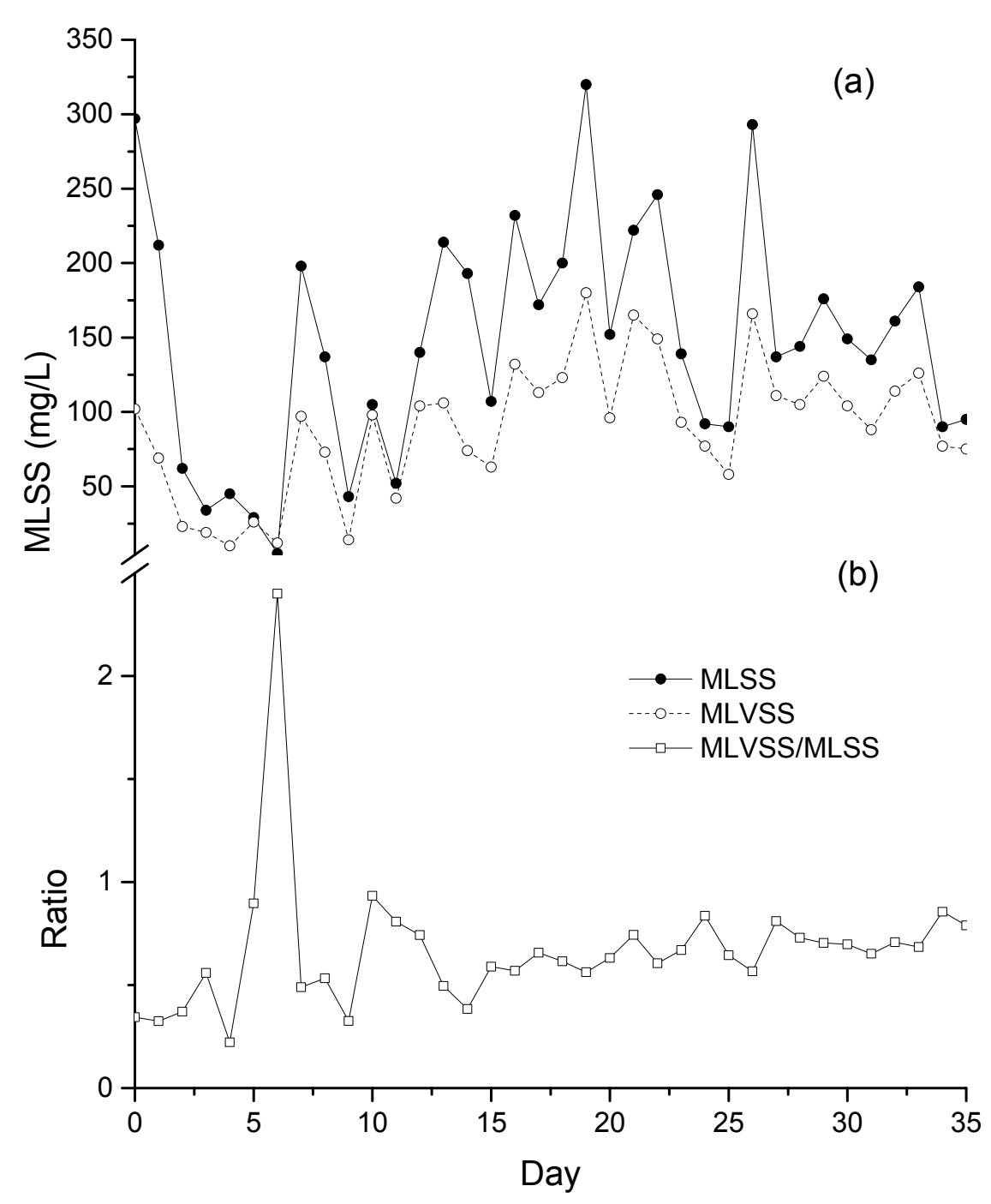

Figure 4. MLSS and MLVSS in the activated sludge in the MBR

\section{Conclusions}

After 35 days of treatment using a laboratory-scale MBR system, the wastewater from production of green bean and barley sprouts was depurated satisfactorily. The effluent could be reused as a principal source of water for bean sprout production. Water quality parameters of the MBR effluent were below or close to the drinking water standards (U.S. Environmental Protection Agency, 2011). At a COD of 10.7, the MBR effluent had a low content of organic pollution. Ammonia was almost removed at $0.038 \mathrm{mg} / \mathrm{L}$, while TSS was only $1 \mathrm{mg} / \mathrm{L}$.

$\mathrm{pH}$ and dissolve oxygen were stabilized during the 35 days of the study, which helped to achieve excellent treatment efficiency. The ratio of MLVSS/MLSS increased to $78.9 \%$, indicating the activated sludge in the bioreactor was rich of bacteria. In future experiments, the treatment method will be further tested in a pilot setup where the MBR effluent will be pumped back directly to a sprout production chamber and circulated for multiple cycles.

\section{Acknowledgements}

The authors would like to acknowledge financial support from Acadia University and the Natural Sciences and Engineering Research Council of Canada (NSERC). In addition, the authors would like to thank Quanwei Alex Wu, Dr. Yiming Zeng, and Huryyah Alamer for technical assistance and sample collection. 


\section{References}

Brown, K., Ghoshdastidar, A. J., Hanmore, J., Frazee, J., \& Tong, A. Z. (2013). Membrane bioreactor technology: A novel approach to the treatment of compost leachate. Waste management, 33, 2188-2194. https://doi.org/10.1016/j.wasman.2013.04.006

Casani, S., Rouhany, M., \& Knøchel, S. (2005). A discussion paper on challenges and limitations to water reuse and hygiene in the food industry. Water research, 39, 1134-1146. https://doi.org/10.1016/j.watres.2004.12.015

Cheremisinoff, N. P. (1994). Handbook of Water and Wastewater Treatment Technology. Taylor \& Francis.

Cisneros, B. E. J., Jiménez, B., \& Asano, T. (2008). Water Reuse: An International Survey of Current Practice, Issues and Needs. IWA Publishing.

Clesceri, L. (1989). Standard methods for the examination of water and wastewater. American Public Health Association: Washington, DC.

Ghoshdastidar, A. J., Saunders, J. E., Brown, K. H., \& Tong, A. Z. (2012) Membrane bioreactor treatment of commonly used organophosphate pesticides. Journal of Environmental Science and Health, Part B, 47, 742-750. https://doi.org/10.1080/03601234.2012.669334

Ghoshdastidar, A. J., \& Tong, A. Z. (2013). Treatment of 2, 4-D, mecoprop, and dicamba using membrane bioreactor technology. Environmental Science and Pollution Research, 20, 5188-5197. https://doi.org/10.1007/s11356-013-1498-z

Goulder, R. (1977). Attached and free bacteria in an estuary with abundant suspended solids. Journal of applied Bacteriology, 43, 399-405. https://doi.org/10.1111/j.1365-2672.1977.tb00766.x

Hach Company. (2005). DR 2800 spectrophotometer procedures manual. Hach Company.

He, Q., Yao, K., Sun, D., \& Shi, B. (2007). Biodegradability of tannin-containing wastewater from leather industry. Biodegradation, 18, 465-472. https://doi.org/10.1007/s10532-006-9079-1

Judd, S. (2011). The MBR Book: Principles and Applications of Membrane Bioreactors for Water and Wastewater Treatment. Elsevier Science.

Knobelsdorf Miranda, J. (2005). Eliminación biológica de nutrientes en un ARU de baja carga orgánica mediante el proceso VIP. Universitat Politècnica de Catalunya. Escola Tècnica Superior d'Enginyers de Camins, Canals i Ports de Barcelona.

Mavrov, V., \& Bélières, E. (2000). Reduction of water consumption and wastewater quantities in the food industry by water recycling using membrane processes. Desalination, 131, 75-86. https://doi.org/10.1016/S0011-9164(00)90008-0

Najafi, M., \& Ma, B. (2009). ICPTT 2009: Advances and Experiences with Pipelines and Trenchless Technology for Water, Sewer, Gas and Oil Applications: October 18-21, 2009, Shanghai, China. American Society of Civil Engineers.

Nollet, L. M. L., \& De Gelder, L. S. P. (2007). Handbook of Water Analysis, Second Edition. Taylor \& Francis. https://doi.org/10.1201/9781420006315

Sichinga, M., Frazee, J., \& Tong, A. Z. (2015). Efficiency and kinetics in treatment of oily wastewater from garages and residential oil spills using membrane bioreactor technology, International Journal of Environmental Science and Technology.

Stephenson, T., Judd, S., Jefferson, B., \& Brindle, K. (2000). Membrane bioreactors for wastewater treatment. Citeseer.

U.S. Environmental Protection Agency. (2011). 2011 Edition of the Drinking Water Standards and Health Advisories.

Woodside, G., \& Kocurek, D. (1997). Environmental, Safety, and Health Engineering. Wiley.

\section{Copyrights}

Copyright for this article is retained by the author(s), with first publication rights granted to the journal.

This is an open-access article distributed under the terms and conditions of the Creative Commons Attribution license (http://creativecommons.org/licenses/by/4.0/). 